International Journal of STEM Education for Sustainability, Vol., No., 2022, pp. 13-31

e-ISSN 2798-5091. DOI. 10.53889/ijses.v2i1.35

\title{
Is Flipped Learning more Effective than Traditional Classrooms in Developing Prospective Elementary Teachers' Competence of Designing Integrated Natural Science Topics?
}

Submitted 22 October 2021, Revised 23 October 2021, Accepted 1 November 2021

Mai The Hung Anh ${ }^{1 *}$, Phan Thi Thanh $\mathrm{Hoi}^{2}$, Phan Duc Duy ${ }^{3}$, Nguyen Thi Thuy Trang ${ }^{4}$

${ }^{1}$ Faculty of Elementary Education, University of education, Hue University, Hue, Vietnam

${ }^{2}$ Faculty of Biology, Hanoi National University of Education, Hanoi, Vietnam

${ }^{3}$ Faculty of Biology, University of education, Hue University, Hue, Vietnam

${ }^{4}$ Faculty of Chemistry, University of Education, Hue University, Hue, Vietnam Corresponding email:*mthanh@hueuni.edu.vn

\begin{abstract}
The flipped learning has a lot of advantages in university teaching, especially in the era of information technology explosion and in response to the current Covid-19 pandemic. Designing integrated natural science topics (DINST) is an important competence of elementary school teachers in creating an attractive teaching topic with interdisciplinary integration. The purpose of this study is to determine the effectiveness of applying the flipped learning in developing DINST competence compared to applying the traditional teaching model for prospective elementary teachers. The article used a quasi-experimental method. The 86 fourth-year pre-service elementary teachers were divided into two groups in which the experimental group was applied the flipped learning and the control group was done by traditional teaching. This research was conducted in a 7-week course in the semester I $(2020$ - 21) through the Module of "Scientific Discovery Activities Organization" at one public university of Education in Vietnam. The article has identified the process of organizing teaching to develop DINST competence for future elementary teachers. Pre- and post- tests were designed and applied on both groups. A questionnaire to collect information on the experimental group's learning attitude was also carried out, which helps to further explain our research results. Descriptive statistics and quantitative data analysis were performed on SPSS. The research results have shown that applying the flipped learning has contributed to the development of DINST competence for prospective elementary teachers better than teaching in the traditional way. The research has contributed to proving the positive role of the flipped learning in developing the future Elementary teachers' competence to integrated teaching and showed that this model can be widely applied in Vietnam's teacher training institutions.
\end{abstract}

Keywords: Flipped learning, Designing integrated topic, Natural science, Competence, Pre-service elementary teacher.

\section{INTRODUCTION}

Flipped learning is also known as "inverted classrooms", "flipped classrooms". It is seen as a form of teaching organization that reversing the traditional concept of classroom-based learning, in which learners are introduced to the learning materials before class, teachers use classroom time to organize for learners to exchange, discuss, problem-solving activities with peers and teachers to deepen understanding of the learning content (Bishop et al., 2013; Hamdan 
International Journal of STEM Education for Sustainability, Vol., No., 2022, pp. 13-32

e-ISSN 2798-5091. DOI. 10.53889/ijses.v2i1.35

et al., 2013; Strayer, 2012). Sams and Bergmann were considered one of the pioneers who laid the groundwork for the flipped learning in 2007. They posted pre-recorded lessons online to help learners re-learn what they missed in their previous lessons instead of re-teaching them. The results were surprising as this made it easier for learners to absorb the lesson content through watching the video over and over again. Since then, the trend has spread and the flipped classrooms have quickly become popular in many American schools (Sams et al., 2012). The flipped learning setting allows students to apply learning theories to more engaging real-life activities, which has improved student engagement as they become more active in discussions with their classmates and develop a collaborative learning environment (Das et al., 2019). Many colleges and universities have adopted the flipped classroom model because it provides opportunities for students to enhance peer-to-peer interaction and deeper engagement with the materials, this pedagogical approach has become so popular in higher education that $2015 \mathrm{New}$ Media Consortium Horizon Report listed the flipping classroom to be adopted on a large scale in a year or less (Johnson et al., 2014).

The flipped learning has been shown to have a positive effect on college learners' academic performance (Zhang et al., 2021). Learners enjoy learning in a flipped classroom environment, they benefited from watching their lessons in condensed lesson videos before class, and technology can provide a self-paced instructional setting that can effectively support the proficient learning for learners (Johnson, 2013). Flipped learning maximizes classroom time, allowing for efficient use of class time if pre-class work is well sequenced and the videos are engaging enough (Fulton, 2012), allowing the lecturers to provide more materials, although learners initially struggled with the new class format, they adapted quickly and found the flipped classroom to be effective, learners engaged the flipped classrooms performed better on equivalence quiz and exam questions and on open-ended design problems (Mason et al., 2013). Therefore, the flipped learning proved to have many advantages in promoting learner autonomy, promoting peer cooperation, developing higher-order thinking, solving problems, thereby improving student capacity and academic achievement (Hamdan et al., 2013). The results of the achievement test scores and final grades of the experimental group under the flipping learning were significantly higher than that of the control group learning according to the traditional classroom (Ozudogru et al., 2019). The improvement in learners' achievement 
International Journal of STEM Education for Sustainability, Vol., No., 2022, pp. 13-32

e-ISSN 2798-5091. DOI. 10.53889/ijses.v2i1.35

at the university level continued to be confirmed by other researchers (Almutairi et al., 2020; Hung et al., 2019).

However, organizing a flip class also poses many challenges such as the high amount of work that makes learners not only had to do more work at home to keep up with the requirements of the flip class compared to previous courses but also must maintain a balance between flipping courses with other courses, which soon caused them to lose interest (Zhao et al., 2014). Students might feel "hidden fear of increased workload and uncertainty of success" (Rotellar et al., 2016). When participating in flipped classrooms for learning environments using intelligent tutoring systems, students were less satisfied and had more psychological instability than students in traditional classrooms (Owens et al., 2007). The use of flipped classrooms could make it difficult for some students to adapt, resulting in not keeping up with their learning progress and unable to participate in group discussions (Tanner et al., 2015). Therefore, students might not fully accept classroom practices when switching from traditional learning to flipping learning (Tomas et al., 2019).

In Vietnam, face-to-face learning, in which teachers and learners interact directly in the classroom during the teaching process, is a traditional teaching model that has been dominant from elementary school to university level (Huong et al., 2002). In this classroom, the teacher or lecturer acts as the central source of knowledge, the transmitter of knowledge, while the students mainly just listen and watch what the lecturer teaches (Luong, 2016; Tuyet, 2013), discussions and debates are rarely used in a classroom environment (Thao et al., 2014). As a result, students become docile to the point of being passive, rarely asking critical questions (Hoa, 2011).

Recently, the flipped learning has also been researched and applied by Vietnamese educators. These studies showed that the application of the flipped learning is much more useful than the traditional classroom, helping to foster better learners' attitudes and learning behaviors (Hung et al., 2019). The flipped classroom setting has a positive impact on students' selfefficacy beliefs and motivation to learn (Thai et al., 2017). Therefore, the learning outcomes of students are said to have improved significantly (Thuong, 2017). However, most of the studies on the applying of flipped classrooms in Vietnam have only focused on learners at the higher education level who are not in the field of teacher training (Hung et al., 2019; Thai et al., 2017; 
International Journal of STEM Education for Sustainability, Vol., No., 2022, pp. 13-32

e-ISSN 2798-5091. DOI. 10.53889/ijses.v2i1.35

Thuong, 2017). Therefore, few people know about the influence of the flipped learning on the formation and development of teaching competencies in teacher training, as well as its influence on the prospective teachers' learning outcomes.

In addition, due to the long-lasting effects of the Covid-19 pandemic in recent years not only has a great impact on the economy and society in Vietnam but also greatly affects the education system in general and universities of education in particular. Pedagogical universities have changed in their approach to teaching, instead of going to class as traditional, have implemented online teaching forms to ensure the progress of training for pre-service teachers. This has greatly challenged the quality of education because many universities, lecturers, and students have not yet adapted to the implementation of teaching and learning by e-learning. However, it is also an opportunity for lecturers and teachers training institutions to change the teaching model to ensure the quality of education.

Therefore, the purpose of this study is to determine the effectiveness of applying the flipped learning in developing pre-service elementary teachers' competence of DINST. In other words, the objective of this study was to investigate whether the flipped learning increases preservice elementary teachers' competency of DINST compared to the traditional classroom model?

\section{METHOD}

\section{Participants}

This research is conducted in a 7-week course in the semester I $(2020-21)$ on 02 groups of 86 fourth-year pre-service elementary teachers who have enrolled in the Module on Organization of Scientific Discovery Activities at one public university of Education in Vietnam. Both groups were developed the competence of DINST. The first group of 45 preservice elementary teachers was selected as the experimental group through the flipped learning and the other group of 41 ones was selected as the control group through the traditional classroom model.

\section{The DINST Competency Framework}

The integrated natural science topic is an interdisciplinary teaching topic, in which the content of knowledge of at least two fields of natural science (such as Biology, Physics, Chemistry, etc.) are organically linked to each other and can further link knowledge content in 
one or more other fields (such as Math, Technology, etc.), this association is made logically, based on realistic context and suitable for students' abilities.

The DINST competence is a component in the integrated teaching competence, which is the ability to analyze, select and combine knowledge contents of at least two natural science fields with each other (such as Biology, Physics, Chemistry, etc.), can further link knowledge content in one or more other fields (such as Math, Technology, etc.), on a basis that is appropriate to the context realistic context and suitable for students' abilities, to build a new integrated topic interdisciplinary. According to our research, the DINST competence framework for pre-service elementary teachers included 9 component competencies as presented in Table 1.

Table 1. The DINST competence framework of pre-service elementary teachers

Component
competence

1. Presenting principles, Learners clearly present the principles of integrated topic integrated topic design design, integrated topic design process, integrated natural process, integrated science topic plan structure.

topic plan structure

2. Build a matrix table Learners can analyze, compare, contrast, synthesize, and find of integrated content connections in the curriculum in the fields of natural science circuits with other subjects at the elementary level. From there, a clear matrix table of content circuits can be built.

3. Name the integrated Learners can name the integrated topic attractive, suitable for topic the integrated content.

4. Identify problems to Learners perform well in selecting and prioritizing the be solved related to problems their students need to solve through integrated integrated topic

5. Build the knowledge content of the integrated topic natural science topic.

Learners can search and select information that is accurate and suitable for their students' cognitive level to build information content, scientific knowledge, and foundation of integrated natural science topic.

6. Build the objectives of the integrated topic

Learners identify and write the objectives of the integrated natural science topic through concretizing the expressions of qualities and competencies that need to be formed and developed for their students through the integrated topic.

7. Identify appropriate teaching methods, Learners identify appropriate teaching methods, techniques, teaching techniques, and means in integrated natural science topic.

and teaching facilities 


\begin{tabular}{|c|c|}
\hline $\begin{array}{l}\text { Component } \\
\text { competence }\end{array}$ & Expression \\
\hline $\begin{array}{l}8 . \text { Build teaching } \\
\text { activities in integrated } \\
\text { topic }\end{array}$ & $\begin{array}{l}\text { Learners can choose teaching methods and techniques, } \\
\text { teaching equipment and means, reasonable teaching } \\
\text { organization form, and allocating appropriate time for } \\
\text { learning activities. }\end{array}$ \\
\hline $\begin{array}{l}\text { 9. Build tools to } \\
\text { evaluate students } \\
\text { through integrated topic }\end{array}$ & $\begin{array}{l}\text { Learners identify the right purpose, select and build a suitable } \\
\text { and effective student assessment toolkit. }\end{array}$ \\
\hline
\end{tabular}

\section{The process of developing pre-service elementary teachers' competency of DINST through the flipped classroom}

The process of developing DINST competence in a 7-week period was conducted in turn through 3 Phases (as shown in Figure 1), each Phase consisted of 4 Stages according to the procedure for organizing flipped classroom about 1 to 3-week period. Each Phase was going to contribute to the development of some components in the DINST competence.

Phase 1
Organize a flipped
classroom to
develop the first 6
component
competencies in the
DINST
competence, from
$1^{\text {st }}$ to $6^{\text {th }}$ component.
Implementation
time in the first 3
weeks.
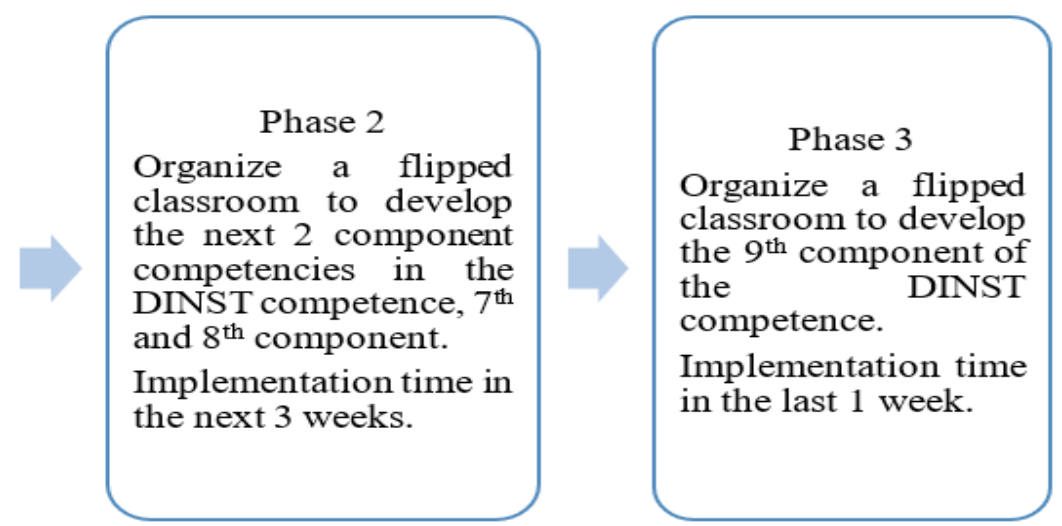

Figure 1. The overall process of developing pre-service elementary teachers' competence of

DINST through the flipped classroom

\section{The Procedure for Organizing Flipped Classroom}

The characteristics of flipped classrooms are different, so we developed a procedure for organizing flipped classrooms to apply to teaching for the experimental group. This procedure was a clear description of the sequence of activities of lecturer and learners within and outside of the classroom as well as the scope of time in order to develop pre-service elementary teachers' competency of DINST. The procedure for organizing the flipped classrooms included 4 Stages; preparation of the lecturer, learners do self-study new knowledge at home, face to face in the class, and after class. The course main period of 7 weeks ( 2 hours per week) was used to organize face to face activities in Stage 3 for all three Phases. In the remaining Stages, 
International Journal of STEM Education for Sustainability, Vol., No., 2022, pp. 13-32

e-ISSN 2798-5091. DOI. 10.53889/ijses.v2i1.35

learners actively self-taught outside of school hours according to the provided learning materials. This procedure will be applied in each Phase in Figure 1. Table 2 illustrated the application of the flipped classroom procedure in Phase 1.

Table 2. The procedure of organizing teaching according to the flipped learning in Phase 1

Stage 1. Preparation of the lecturer

+ Identify the content learners will self-study at home and interact in the classroom. Specifically, learners will self-study at home the theoretical contents of principles, integrated topic design process, integrated topic plan structure. In class, they will discuss and do practical exercises related to the content they have studied before such as building a matrix table of integrated content circuits; identify the problems to be solved related to the integrated topic; building content knowledge of the integrated topic; establish objectives and name the integrated topic.

+ Design interactive online content for learners to self-study at home such as building video content of electronic lectures and material related to previously defined content; design exercises and tests on "Designing integrated topics".

+ Develop practical exercises to organize learners to practice in the classroom.

+ Develop guidelines, study plans and policies for learners.

+ Designing teaching plans, including choosing teaching methods and means; selection of forms and methods; developing tools for testing and evaluation; building a process of teaching activities at home and in class.

\begin{tabular}{c} 
Stage 2. Learners do self-study new knowledge at home \\
\hline- Activites of lecto
\end{tabular}

- Activities of lecturer

+ Firstly, upload guidelines and study policies for learners; upload materials and lectures videos, exercises, and tests related to the content prepared in stage 1 to the Google Classroom.

+ Secondly, provide learning accounts on Google Classroom for learners.

+ Thirdly, asking learners to implement the pre-test "Designing integrated topic".

+ Then, asking learners to self-study materials and lecture videos, and do practical exercises themselves.

+ Finally, monitor and support learners during their self-study at home.

\begin{tabular}{ll}
\hline \multicolumn{1}{c}{ Stage 3. Face to face in the class } \\
\hline - Activities of lecturer & - Activities of learners \\
+ Check learners' understanding of new & + State the problems and exercises not \\
knowledge they have studied themselves. & understood in the process of self-study. \\
\hline & 19
\end{tabular}

- Activities of learners

Learners perform activities corresponding to the activities of the lecturer. Specifically,

+ Log in Google Classroom according to the account provided by the lecturer, read the study instructions.

+ Take and submit pre-tests.

+ Conduct self-study of new knowledge through materials and lectures videos.

+ Do and submit practical exercises (first time) on Google classroom.

+ Prepare questions about unknown issues or other questions related to the learning content for the face-to-face session. 
+ Organize discussions to solve exercises and learners' questions related to new knowledge.

+ Organize learners to discuss and solve practical exercises.

+ Ask learners, after this class, to continue

to edit, complete and submit these exercises (second time) in the Google classroom. Notify learners of virtual discussion rooms (through social media such as Zalo, Facebook, Padlet, etc.) for learners to continue discussing (if learners have demands) related to completing that exercise.
+ Discuss and solve problems and exercises that learners do not understand based on the organization of the lecturer.

+ Discuss and present practical exercises provided by the lecturer.

+ Take notes of learned problems.
- Activities of lecturer

+ If learners have any wonders during the process of completing practical exercises (second time), continue to discuss and answer questions more deeply in virtual classrooms.

+ Evaluate exercises after learners complete them.

+ The lecturers self-assess the advantages and limitations after implementing the teaching in the flipped classroom, thereby making more suitable adjustments for the following lesson.

+ Move to stage 1 to organize teaching new content in Phase 2.

\section{Measurement}

\section{The DINST competence test}

The test "Integrated topic design" with essay form, used for both the experimental and the control groups aims to assess pre-service elementary teachers' competence of DINST at both the pre- and post-course. This test consists of 2 tasks with 10 small questions. Task 1 aims to assess the $1^{\text {st }}$ component competence, by asking learners to present the principles and process of designing integrated topic, and the structure of integrated natural science topic plans. Task 2 aims to evaluate the remaining component competencies, involving asking learners to analyze the actual context and the curriculum of elementary school subjects, thereby selecting closely 
International Journal of STEM Education for Sustainability, Vol., No., 2022, pp. 13-32

e-ISSN 2798-5091. DOI. 10.53889/ijses.v2i1.35

related contents to build an integrated natural science topic in teaching at the elementary level. This task is suggested by open-ended questions related to (1) Name the topic, determine the teaching time; (2) Building the matrix and specific integrated contents; (3) Define the goal of the integrated topic; (4) Identify appropriate teaching methods, techniques, and aids in integrated teaching activities; (5) Building a tool to evaluate students through integrated topic.

\section{Survey questionnaire}

A survey questionnaire was used on the experimental group after applying the flipped learning to collect more feedback on learners' attitudes towards this model. The content of the survey was presented in Table 6. The 10-item survey tool was performed using a 5-point Likert scale ("1" = absolutely disagree, " 2 " = disagree, " 3 " = neutral, " 4 " = agree, " 5 " = absolutely agree), Cronbach's alpha values were calculated evenly above .842 , all variables Corrected Item-Total Correlation $\geq .3$ are appropriate. Kaiser-Meyer-Olkin $=.733$, Bartlett's Test $=.000$, Eigenvalues $=1.055$, Total Variance Explained $=80.243 \%$, Factor loading $\geq .3$. From the analysis results showed the survey table ensured the reliability and validity of the scale. This tool has been improved from research by Pierce (Pierce et al., 2012) to suit the content of developing DINST competence for pre-service elementary teachers in Vietnam. We have chosen Pierce's tool because it is similar to our research purpose of understanding learners' attitudes when applying the flipped classroom model. The article's items Q4, Q5, Q7, Q9 and Q10 (as presented in Table 6) were used entirely from Pierce's tool. However, the Pierce's tool used to survey the audience is pharmacy students, we changed some details in the items to be suitable for pedagogical students. For instance, "I want more interaction between students and faculty members in class" was rephrased to "I want more time in class to practice integrated theme design". We completely replaced "The flipped classroom model was similar to other classes in the Bernard J. Dunn School of Pharmacy" item with "Flipped classroom activities helps me deepen my understanding of key concepts" item.

\section{Implementation}

The experimental and the control groups were taught by the same lecturer in two different times and classrooms. Both classes are required to attend 2 hours weekly during the first semester of the 2020-21 school year. In which, the experimental group were taught according to the process of developing DINST competence through the flipped classroom (as shown in 
International Journal of STEM Education for Sustainability, Vol., No., 2022, pp. 13-32

e-ISSN 2798-5091. DOI. 10.53889/ijses.v2i1.35

Figure 1) and the Procedure for Organizing Flipped Classroom (as shown in Table 2). In the first Stage, learners were self-studying online at home with content videos and materials under the guidance of a lecturer on the DINST's process. In order to increase the participation rate and monitor the class at home, learners are required to complete exercises and tests at the level of knowledge and understanding on the Bloom scale (Bloom, 1956) After learners complete assignments, they need to be uploaded to the Google Classroom before coming to class. During the face-to-face Stage, the learners were not re-taught the content in the learned at home video previously, only the important content that they did not understand will be explained. The class time was completely used to discuss, answer questions and do practical exercises to apply selfstudy knowledge of DINST.

The control group is taught by traditional learning, learners were not organized to study new knowledge by themselves at home, learners could only form theoretical and practical knowledge about DINST based on direct lectures by teachers in class. Tests, practice exercises, applications to design integrated natural science topics are mainly conducted as a form of homework.

All learning materials used in the flipped teaching model including videos, course content, pre- and post-tests were provided to the experimental and control groups. In addition, the experimental group would conduct more the questionnaire after completing the course.

\section{Data collection and Analysis}

For the first research question (Is there any difference in effectiveness in developing the pre-service elementary teachers' competence of DINST between the flipped classroom and the traditional teaching model?), both experimental and control groups took the pre-test "Integrated topic design" in order to assess learners' initial DINST competence. After the course, both groups were carried out the post-test to evaluate and compare the effectiveness of the competence development of DINST between the flipped classroom teaching and the traditional teaching models. Learners' competence scores were scored on a 10-point scale of Vietnam, divided into 4 levels from low to high, corresponding to levels from 1 to 4 . In which, learners with scores below 5.0 are low competence, from 5.0-6.4 are medium competence, from 6.5-7.9 are fair competence, and above 8.0 are good competence. Due to the sample size was small and the data did not meet the assumptions of the parametric test (Conover, 1999), the 
International Journal of STEM Education for Sustainability, Vol., No., 2022, pp. 13-32

e-ISSN 2798-5091. DOI. 10.53889/ijses.v2i1.35

scores from the tests were compared by quantitative analysis, using the Mann Whitney $\mathrm{U}$ nonparametric test and the Wilcoxon signed rank test (Fay et al., 2010). The Mann-Whitney U test was implemented to detect the difference in DINST competence before and after the course of the experimental and control groups. Wilcoxon signed rank test was applied to examine changes in the learning outcome of the development of DINST competence within each group separately.

For the second research question (What is the attitude of pre-service elementary teachers when learning in the flipped learning?), we conducted a survey using a questionnaire on the experimental group after completing the course. The data were analyzed by descriptive statistics on SPSS software to further explain our research results obtained from previous qualitative analysis results.

\section{RESULTS AND DISCUSSION}

The application of the flipped learning was more effective in developing the competence of DINST for pre-service elementary teachers than the traditional teaching model

Instead of solving the first research question, we in turn solved three sub-problems through Quantitative Analysis of the collected data, as detailed below.

How is the pre-service elementary teachers' competence to DINST in the experimental and the control groups before taking the course? Is there any difference in this competence between the experimental and the control groups before impact?

Table 3. Analysis of the pre-test score of the experimental and the control groups

\begin{tabular}{cccccccc}
\hline Groups & N & Mean & $\begin{array}{c}\text { Mean } \\
\text { Rank }\end{array}$ & $\begin{array}{c}\text { Sum of } \\
\text { Ranks }\end{array}$ & $\begin{array}{c}\text { U- } \\
\text { value }\end{array}$ & Z-value & P-value \\
\hline $\begin{array}{c}\text { Experimental } \\
\text { Group }\end{array}$ & 45 & 3.24 & 44.49 & 2002.00 & 878.00 & -.403 & .687 \\
Control Group & 41 & 3.17 & 42.41 & 1739.00 & & \\
\hline
\end{tabular}

We analyzed the scores of the pre-test, using Mann Whitney U Test. The results shown in Table 3 showed that the mean score of the test before the impact of the experimental and the control groups was scored on a very low 10-point scale of 3.24 and 3.17, respectively. The pretest scores for both groups did not show statistical difference $(U=878.00 ; p=.687>.05)$. These results proved that the pre-service elementary teachers' competence of DINST before teaching in the flipped classroom and the traditional model was very low. And there was no difference in this competence between learners in the experimental and the control groups before the course. 
International Journal of STEM Education for Sustainability, Vol., No., 2022, pp. 13-32

e-ISSN 2798-5091. DOI. 10.53889/ijses.v2i1.35

Can the application of the flipped classroom as well as the traditional classroom model develop the pre-service elementary teachers' competence of DINST?

We used the Wilcoxon Signed-Ranks Test to analyze the difference in the post-test scores compared with the pre-test scores of both the experimental and control groups. The results shown in Table 4 showed that the experimental group has affected by the flipped learning. There was a statistically significant difference in the mean score of the post- and pre-test $(\mathrm{Z}=$ $6,014 ; \mathrm{p}=.000<.005)$. The DINST competence of pre-service elementary teachers improved significantly, specifically the mean score increased from 3.24 in the pre- to 8.16 in the posttest. The significant increase in pre-service elementary teachers' integrative topic design competence was not coincidental, it was due to the impact of the flipped learning. This result was similar to the control group affected by the traditional classroom model, in which the mean score of the post-test increased significantly compared to the pre-test (from 3.17 to 7.02 ), this development also did not happen by chance $(Z=-5.724 ; \mathrm{p}=.000<.005)$.

Table 4. Analysis of the difference between the post- and pre-test scores of the experimental and the control groups

\begin{tabular}{cccccccc}
\hline \multicolumn{2}{c}{ Groups } & $\mathrm{N}$ & Mean & $\begin{array}{c}\text { Mean } \\
\text { Rank }\end{array}$ & $\begin{array}{c}\text { Sum of } \\
\text { Ranks }\end{array}$ & Z-value & P-value \\
\hline Experimental & pre-test scores & 45 & 3.24 & 23.00 & 1035.00 & -6.014 & .000 \\
Group & $\begin{array}{c}\text { post-test scores } \\
\text { pre-test scores }\end{array}$ & 41 & 8.16 & & & & \\
Control Group & $\begin{array}{c}3.17 \\
\text { post-test scores }\end{array}$ & & 7.02 & 21.00 & 861.00 & -5.724 & .000 \\
\hline
\end{tabular}

\section{Is there any difference in the level of development of the prospective elementary teachers' competence of DINST between the flipped and the traditional classrooms?}

We further analyzed the post-test scores, using the Mann Whitney U Test. The results shown in Table 5 showed that there was a statistically significant difference in the mean score of the post-test between the experimental and the control groups $(U=378.00 ; p=.000<.05)$, in which mean score of the post-test of the experimental was 1.14 higher than that of the control group $(8.16 ; 7.02)$. This proved that the competence of DINST of the experiment affected by the flipped learning is higher (reaching a good level of competence) than the control group taught by the traditional method (reaching a fair level of competence).

Table 5. Analyze the post-test score of experimental and control groups 
International Journal of STEM Education for Sustainability, Vol., No., 2022, pp. 13-32

e-ISSN 2798-5091. DOI. 10.53889/ijses.v2i1.35

\begin{tabular}{lccccccc}
\hline Groups & $\mathrm{N}$ & Mean & $\begin{array}{c}\text { Mean } \\
\text { Rank }\end{array}$ & $\begin{array}{c}\text { Sum of } \\
\text { Ranks }\end{array}$ & U-value & Z-value & P-value \\
\hline $\begin{array}{l}\text { Experimental } \\
\quad \text { Group }\end{array}$ & 45 & 8.16 & 55.60 & 2502.00 & 378.00 & -4.887 & .000 \\
Control Group & 41 & 7.02 & 30.22 & 1239.00 & & & \\
\hline
\end{tabular}

\section{The attitude of pre-service elementary teachers when learning in the flipped learning}

To solve the second research question (What is the attitude of pre-service elementary teachers when learning in the flipped learning?), we conducted Qualitative Analysis, calculated the reliability, mean and standard deviation of each variable based on the results collected from 45 valid respondents to the survey of the experimental group by the flipped learning. The results of descriptive statistics of the survey variables were shown in Table 6. More than $93.3 \%$ people agree and absolutely agree with the important role of the lecturer in attracting learners to participate in the flipped classroom (Q7), as well as the effect of flipped classroom activities helped learners deepen their understanding of key concepts (Q6). The survey results with a high agreement rate from $80 \%$ to $88.4 \%$ showed that learners had a positive attitude not only during self-study at home (Q1, Q2, Q3, Q4, Q9) but also during active interaction in class (Q5, Q8). However, the agreement rate of Q10 accounted for 71.1\% showing there was not a high consensus on wishing more teachers would adopt the flipped learning. Overall, the survey results indicated that most of the experimental group gave positive feedback on the flipped classroom activities. Thereby, pre-service elementary teachers had a positive attitude when learning in this model.

Table 6. Descriptive Statistics on attitudes of pre-service elementary teachers when learning in the flipped learning

\begin{tabular}{|c|c|c|c|c|c|c|}
\hline Questionnaire Items & $\mathrm{N}$ & Min & Max & Mean & SD & $\begin{array}{l}\% \text { Agree } \\
(\mathrm{AA}+\mathrm{A})\end{array}$ \\
\hline $\begin{array}{l}\text { Q1. The lecturer's video lectures were attractive and } \\
\text { easy to understand }\end{array}$ & 45 & 3.00 & 5.00 & 4.13 & .660 & 84.5 \\
\hline $\begin{array}{l}\text { Q2. I was active in self-studying video lectures and } \\
\text { learning materials at home under the guidance of the } \\
\text { lecturer }\end{array}$ & 45 & 3.00 & 5.00 & 4.00 & .603 & 82.2 \\
\hline $\begin{array}{l}\text { Q3. I watched the lecture video again when I didn't } \\
\text { really understand the problem }\end{array}$ & 45 & 2.00 & 5.00 & 3.86 & .660 & 80.0 \\
\hline $\begin{array}{l}\text { Q4. Viewing the pre-recorded lecture was essential to } \\
\text { successfully participating in the class activity }\end{array}$ & 45 & 3.00 & 5.00 & 4.13 & .625 & 86.7 \\
\hline
\end{tabular}


International Journal of STEM Education for Sustainability, Vol., No., 2022, pp. 13-32

e-ISSN 2798-5091. DOI. 10.53889/ijses.v2i1.35

Q5. The instructor made meaningful connections between the topics in the pre-recorded lecture and the class activity

Q6. Flipped classroom activities helps me deepen my understanding of key concepts

$\begin{array}{llllll}45 & 3.00 & 5.00 & 4.06 & .617 & 88.4\end{array}$

Q7. The lecturer attracted me in the Flipped Learning activity

$\begin{array}{llllll}45 & 3.00 & 5.00 & 4.13 & .504 & 93.3\end{array}$

$\begin{array}{llllll}45 & 3.00 & 5.00 & 4.15 & .520 & 93.3\end{array}$

Q8. I want more time in class to practice integrated

theme design

$\begin{array}{llllll}45 & 3.00 & 5.00 & 3.88 & .438 & 84.4\end{array}$

Questionnaire Items

$\mathrm{N}$ Min Max Mean SD (AA +

A)

Q10. I wish more instructors used the "flipped classroom" model

$\begin{array}{llllll}45 & 2.00 & 5.00 & 3.66 & .639 & 71.1\end{array}$

${ }^{*} A A+$ A: Absolutely Agree + Agree; SD: Std. Deviation

According to research results from quantitative analysis, the application of the flipped classroom has proved to be more effective than the traditional classroom models in developing the pre-service elementary teachers' competency of DINST. This result has contributed to confirm the previous studies of the positive effect that the flipped classroom brings compared to the traditional classroom in training pre-service teachers (Almutairi et al., 2020; Hung et al., 2019; Ozudogru et al., 2019). This may stem from the difference between the flipped classroom and the traditional teaching models as shown in Table 2 , in this way, it has positively influenced student learning. The implementation of the flipping learning method has given learners in the experimental group more time to research new knowledge, more autonomy under the support of information technology, contributing to increased proficient and their achievement compared to the control group like Johnson's study (Johnson, 2013), this is also in line with the research of Fulton (Fulton, 2012). Understanding the background knowledge before going to class has promoted active participation of learners in classroom learning, learners have more opportunities to interact, learn from each other and learn more deeply under the supervision of the lecturer at the classroom. As a result, learners have more opportunities to develop and improve their competencies, which has been confirmed in Mason's studies (Mason et al., 2013). Based on descriptive data from qualitative analysis results, it showed that pre-service elementary teachers had a positive attitude when learning in the flipped learning. This has contributed to explain more about the high effectiveness of the flipped learning in developing their competence to build integrated natural science topics. The instructor's easy-to-understand 
International Journal of STEM Education for Sustainability, Vol., No., 2022, pp. 13-32

e-ISSN 2798-5091. DOI. 10.53889/ijses.v2i1.35

and engaging lectures video along with clear instructions not only facilitate learners' initiative in self-studying video lectures, study materials at home but also giving them the opportunity to review the video any time they need it or rewrite the questions if they don't understand it, thus giving them a deeper understanding of the material. This result is consistent with Johnson's conclusion when he suggested that learners in flipped classrooms benefit from watching lectures in condensed video lessons (Johnson, 2013). This has contributed to increasing learners' achievement as published in the studies by Almutairi and Sams (Almutairi et al., 2020; Sams et al., 2012). However, the survey results showed that although learners have high learning efficiency, there were still many students who did not wish many lecturers to apply this model in teaching. In other words, some learners still absolutely disagree with the transition from traditional learning to blended learning methods as studied by Tomas (Tomas et al., 2019), psychological reluctance to face changes, possibly because pre-service teachers feel a lot of pressure and overload with the number of tasks to perform in the learning process as in the previous studies (Owens et al., 2007; Rotellar et al., 2016; Zhao et al., 2014). This result was not similar to Johnson's research, which suggested that learners prefer to learn in a flipped classroom environment (Johnson, 2013). Teachers in the flipped learning not only play a very important role in orienting students' learning through designing learning videos and homework, but also guide and organize deeper learning activities through meaningful connections between pre-recorded lecture topics with classroom activities. By completely focusing on organizing classroom activities for pre-service teachers to discuss, applying self-study knowledge to practice integrated topic design in class will help students deepen their understanding of key concepts, and be more confident in their ability to design new integrated topics. That could be one of the important reasons why the competence development of learners in the flipped classroom is more effective than in the traditional classroom. This is consistent with the view of den Brok et al who argue that the interpersonal behavior of teachers was significantly related to student learning outcomes (den Brok et al., 2004). Therefore, it can be said that the increased interaction between lecturers and students can be one of the reasons for the good academic performance of learners in the flipped learning. 
International Journal of STEM Education for Sustainability, Vol., No., 2022, pp. 13-32

e-ISSN 2798-5091. DOI. 10.53889/ijses.v2i1.35

\section{CONCLUSION}

Research showed that the flipped classroom is more effective than the traditional classroom model in developing DINST competence for prospective elementary teachers. In addition, the positive attitude of pre-service elementary teachers when participating in the flipped learning has contributed to further elucidating the high efficiency of this model in developing their competence to build integrated topics. The research results have added a practical basis in Vietnam in applying the flipped learning in higher education institutions with teacher training, and showed that the flipped learning can be used to form and develop pedagogical competencies for pre-service teachers.

\section{SUGGESTIONS}

One of the limitations of this study is that the study sample was small which resulted in the sampling method being non-probability, with only participants who were relevant to the study selected. It may therefore result that results cannot be generalized to the entire population and that the findings are not explained beyond the sampled population. In addition, this study only deals with the development of DINST competence for pre-service elementary teachers - a small unit in the teaching competence system. In future studies, it is necessary to further study the feasibility of the flipped learning method in the units related to other competencies in the integrated teaching competence and to increase the sample size large enough to reduce the influence of over-reliance on available participants to ensure that the results obtained are realistically representative. In addition, there should be improvements in the process of organizing flipped classrooms such as editing the content to be more concise and clear, focusing only on the necessary information content to support the development of DINST competence for prospective elementary teachers. Instead of providing students with many homework exercises with similar content to the main exercises to help students have the opportunity to practice more skills, reduce the number of those exercises. Thereby helping to reduce the workload of students in the self-study stage, contributing to increasing the demand for learning according to the flipped learning among learners.

\section{ACKNOWLEDGEMENT}

The authors would like to thank anonymous reviewers and the scientific committee of Conference "Innovation in Learning Instruction and Teacher Education" conducted at Hanoi 
International Journal of STEM Education for Sustainability, Vol., No., 2022, pp. 13-32

e-ISSN 2798-5091. DOI. 10.53889/ijses.v2i1.35

National University of Education in Vietnam for their comments and suggestions to improve the quality of paper before it be submitted to the journal. In addition, we would like to thank Institute of Big Data for its support in this research. Information about the sponsorship is that Mai Thế Hùng Anh was funded by Vingroup JSC and supported by the Master, PhD Scholarship Programme of Vingroup Innovation Foundation (VINIF), Institute of Big Data, code VINIF.2021.TS.150.

\section{REFERENCES}

Almutairi, F., Almodaires, A., \& Zeyab, A. (2020). Effectiveness of Flipped Learning: Improving Pre-Service Teachers' Prowess in Producing Videos. International Education Studies, 13, 163. doi: 10.5539/ies.v13n7p163.

Bishop, J. L., \& Verleger, M. (2013). The flipped classroom: A survey of the research. ASEE Annual Conference and Exposition, Conference Proceedings.

Bloom, B. (1956). Taxonomy of educational objectives: Handbook I: Cognitive domain. Conover, W. (1999). Practical Nonparametric Statistics-Third Edition.

Das, A. K., Nguyen, Q., Nguyen, A., Nomikoudis, M., \& Van, D. H. (2019). Course redesign to incorporate flipped delivery: A business degree case in Vietnam. Issues in Educational Research, 29, 363-383.

den Brok, P., Brekelmans, M., \& Wubbels, T. (2004). Interpersonal Teacher Behaviour and Student Outcomes. School Effectiveness and School Improvement, 15(3-4), 407-442. doi: 10.1080/09243450512331383262.

Fay, M., \& Proschan, M. (2010). Wilcoxon-Mann-Whitney or t-test? On assumptions for hypothesis test and multiple interpretations of decision rules. Statistics surveys, 4, 1-39. doi: 10.1214/09-SS051.

Fulton, K. (2012). Upside down and inside out: Flip your classroom to improve student learning. Learning \& Leading with Technology, 39, 12-17.

Hamdan, N., McKnight, P., \& McKnight, K. (2013). Review of Flipped Learning. doi: 10.4236/ce.

Hoa, N. (2011). Primary English language education policy in Vietnam: Insights from implementation. Current Issues in Language Planning, 12, 225-249. doi: 10.1080/14664208.2011.597048.

Hung, T., Yellishetty, M., Thanh, N., Patil, A., \& Huy, L. (2019). The Application of Flipped Classroom in Teaching University Students: Concepts, Methodologies, Tools, and Applications, 1473-1485. 
International Journal of STEM Education for Sustainability, Vol., No., 2022, pp. 13-32

e-ISSN 2798-5091. DOI. 10.53889/ijses.v2i1.35

Huong, P., \& Fry, G. (2002). The Emergence of Private Higher Education in Vietnam: Challenges and Opportunities. http://lst-iiep.iiep-unesco.org/cgibin/wwwi32.exe/[in=epidoc 1.in]/?t2000=019616/(100), $1 . \quad$ doi: 10.1023/A:1021130320485.

Johnson, G. (2013). Student perceptions of the Flipped Classroom.

Johnson, L., Adams Becker, S., Estrada, V., \& Freeman, A. (2014). NMC Horizon Report: 2014 library edition. Austin, Texas: The New Media Consortium. Retrieved January 8, 2021, from https://privacytools.seas.harvard.edu/files/privacytools/files/2014-nmc-horizonreport-library-en.pdf.

Luong, G. (2016). Achieving change in student assessment in Vietnamese teacher training institutions. 149, 98-99.

Mason, G., Rutar Shuman, T., \& Cook, K. E. (2013). Comparing the Effectiveness of an Inverted Classroom to a Traditional Classroom in an Upper-Division Engineering Course. Education, IEEE Transactions on, 56, 430-435. doi: 10.1109/TE.2013.2249066.

Owens, D. T., \& Strayer, J. F. (2007). The effects of the classroom flip on the learning environment: a comparison of learning activity in a traditional classroom and a flip classroom that used an intelligent tutoring system.

Ozudogru, M., \& Aksu, M. (2019). Pre-service teachers' achievement and perceptions of the classroom environment in flipped learning and traditional instruction classes. Australasian Journal of Educational Technology, 27-43. doi: 10.14742/ajet.5115.

Pierce, R., \& Fox, J. (2012). Vodcasts and Active-Learning Exercises in a "Flipped Classroom" Model of a Renal Pharmacotherapy Module. American journal of pharmaceutical education, 76, 196. doi: 10.5688/ajpe7610196.

Rotellar, C., \& Cain, J. (2016). Research, Perspectives, and Recommendations on Implementing the Flipped Classroom. American journal of pharmaceutical education, 80 .

Sams, A., \& Bergmann, J. (2012). Flip Your Classroom: Reach Every Student in Every Class Every Day.

Strayer, J. (2012). How learning in an inverted classroom influences cooperation, innovation and task orientation. Learning Environments Research, 15, 171-193. doi: 10.1007/s10984-012-9108-4.

Tanner, M., \& Scott, E. (2015). A Flipped Classroom Approach to Teaching Systems Analysis, Design and Implementation. 
Thai, N. T. T., Wever, B., \& Valcke, M. (2017). The impact of a flipped classroom design on learning performance in higher education: Looking for the best "blend" of lectures and guiding questions with feedback. Comput. Educ., 107, 113-126.

Thao, D., Bac-Ly, D., \& Yuenyong, C. (2014). Learning environment in Vietnamese physics teacher education programme through the lens of constructivism: a case study of a state university in Mekong delta region, Vietnam. International Journal of Science and Mathematics Education, 14. doi: 10.1007/s10763-014-9585-2.

Thuong, N. (2017). Implementation of English flipped classrooms: Students' perceptions and teacher's reflection. International Journal of Research Studies in Language Learning, 7. doi: 10.5861/ijrsll.2017.1876.

Tomas, L., Evans, N., Doyle, T., \& Skamp, K. (2019). Are first year students ready for a flipped classroom? A case for a flipped learning continuum. International Journal of Educational Technology in Higher Education, 16, 1-22.

Tuyet, T. T. (2013). Limitation on the development of skills in higher education in Vietnam. Higher Education, 65. doi: 10.1007/s10734-012-9567-7.

Zhang, Q., Cheung, E., \& Cheung, C. (2021). The Impact of Flipped Classroom on College Students' Academic Performance: A Meta-Analysis Based on 20 Experimental Studies. Science Insights Education Frontiers, 8, 1059-1080. doi: 10.15354/sief.21.re019.

Zhao, Y., \& Ho, A. D. (2014). Evaluating the Flipped Classroom in An Undergraduate History Course. 